Нсйчева Лілія Василівна,

кандидат мистецтвознавства, завідувач літературно-драматургічної частини Одеського національного академічного театру опери та балету

ORCID 0000-0002-9952-0385

Liliya.neicheva@gmail.com

\title{
НАЦІОНАЛЬНІ ОСОБЛИВОСТІ БОЛГАРСЬКОЇ МОВИ І ТРАДИЦІЇ НАЦІОНАЛЬНОГО ВОКАЛУ
}

\begin{abstract}
Мета статті - розглянути особливості фонетики болгарської мови та іiі вплив на формування болгарського вокалу. Методологічною основою роботи виступає інтонаційна концепція музики, яка представлена послідовником Б. Асаф'єва в Україні І. Ляшевським [7]. Теоретичні розробки дослідників Д. Гачева [4; 5], М. Ремньової [11], Т. Попової [10], які присвячені етапам формування й розвитку фонетики болгарської мови, природним факторам, що вплинули на ії специфіку. Наукова новизна - вперше зроблено узагальнення про тембральні переваги болгарської церковної та оперної музики у зв'язку з мовною фонетикою цієї країни. Висновки. Проаналізувавши специфічні риси виконання творів болгарським оперним співаком Іваном Вульпе, болгарською естрадною співачкою Лілі Івановою, спів якої асоціюється з «серйозністю» через низькі форманти мови, манеру виконавиці народних болгарських пісень Валі Балканської дійшли до висновку, що мовна фонетика Болгарії є показником національної особливості болгар і стала основним фактором популярності й затребуваності співаків з цієї країни. Завдяки сонорності мови, ії опори на голосні звуки, що формують нижні форманти, Болгарія славиться своїми басами. Це пояснює поширення в церковному співі країни «басової традиції» виконання в храмах та створення для цього голосу сольних партій. Релігійна строгість болгарської традиції у поєднанні зі сприятливими фонетичними умовами зумовила вагомість болгарського вокалу в світовому вираженні цього мистецтва, а значимість басового співу для болгар в опері недвозначно змикається з церковною традицією. Звучання низьких голосів пов'язане в староцерковній традиції 3 серйозністю, що особливо важливо для усвідомлення Християнської ідеї.

Ключові слова: фонетика болгарської мови, сонорність, Іван Вульпе, Валя Балканська, болгарська
\end{abstract} оперна школа.

Нейчева Лилия Васильевна, кандидат искусствоведенья, заведующая литературно-драматической частью Одесского национального академического театра оперы и балета

\section{Национальные особенности болгарского языка и традиции национального вокала}

Цель статьи - рассмотрение особенности фонетики болгарского языка и ее влияние на формирование болгарского вокала. Методологической основой работы выступает интонационная концепция музыки, которая представлена последователем Б. Асафьева в Украине И. Ляшевским [7]. Теоретические разработки исследователей Д. Гачева[5; 6], М. Ремневой[11], Т. Поповой [10], которые посвящены этапам формирования и развития фонетики болгарского языка, природным факторам, повлиявшим на ее специфику. Научная новизна - впервые сделано обобщение о тембральных преимуществах болгарской церковной и оперной музыки в связи с языковой фонетикой этой страны. Выводы. Проанализировав специфические черты исполнения произведений болгарским оперным певцом Иваном Вульпе, болгарской эстрадной певицей Лили Ивановой, пение которой ассоциируется с «серьезностью» из-за низких формант языка, манеру исполнительницы народных болгарских песен Вали Балканскойпришли к выводу, что языковая фонетика Болгарии является показателем национальной особенности болгар и стала основным фактором популярности и востребованности певцовэтой страны. Благодаря сонорности языка, его опоры на гласные звуки, которые формируют нижние форманты, Болгария славится своими басами. Это объясняет распространение в церковном пении страны «басовой традиции» исполнения в храмах и написание для этого голоса сольных партий. Религиозная строгость болгарской традиции в сочетании с благоприятными фонетическими условиями предопределила значимость болгарского вокала в мировом выражении этого искусства, а значимость басового пения для болгар в оперном искусстве недвусмысленно смыкается с церковной традицией. Звучание низких голосов связано в староцерковной традиции с серьезностью, что особенно важно для понимания Христианской идеи.

Ключевые слова: фонетика болгарскогоязыка, сонорность, Іван Вульпе, Валя Балканская, болгарская оперная школа.

Nieicheva Liliia, PhDinArts, head of the literary and dramatic part of the Odessa National Academic Theatre of Opera and Ballet

National specifics of the Bulgarian language and national singing traditions

(C) Нєйчева Л. В., 2019 
The purpose of the article is to study the specifics of the Bulgarian language's phonetics and its effect on the formation of Bulgarian singing. The methodology of this work is provided by intonation concept of music represented by I. Liashevsky[7], BorisAsafyev's follower in Ukraine [10]. And also, by theoretical findings of the scholars D. Gachev[5; 6], M. Remnyova [11] and T. Popova[10] who studied the formation and development of the Bulgarian language's phonetics and natural factors that affected its specifics. Scientific novelty: for the first time, a generalization was made regarding timbral advantages of Bulgarian religious and opera music in connection with phonetics of the Bulgarian language. Conclusions. Having analyzed the performances of the Bulgarian opera singer Ivan Vulpe and the Bulgarian pop singer Lili Ivanova, whose singing is being associated with the «seriousness» due to low language formats, and ValyaBalkanska's manner of singing Bulgarian folk songs, we have arrived at the conclusion that the Bulgarian language's phonetics is an indicator of the national specifics of Bulgarians, which became the main factor that contributed to popularity of and demand for Bulgarian singers. Thanks to the sonority of language and its emphasis on vowels that form lower formants, Bulgaria is famous for its bass singers. It explains the predominance in the country's religious singing of the "bass tradition" of performance in churches and the writing of solo parts for this pitch, in which it not only serves as the harmonious basis for chords but also has a sophisticated melodious structure. Religious austerity of Bulgarian tradition combined with favorable phonetic features translates into the importance of Bulgarian signing in the global dimension of this art, while the significance of opera bass singing for Bulgarians unambiguously interlocks with religious tradition. In medieval Christian tradition, low pitch sound is related to the seriousness, which is especially important for the perception of the Christian idea.

Key words: phonetics of the Bulgarian language, sonority, Ivan Vulpe, ValyaBalkanska, Bulgarian opera school.

Актуальність дослідження визначена важливістю болгарської ідеї в сучасному музичному світі та затребуваністю в світовому оперному світі виконавців з цієї країни. Методологічною основою роботи виступає інтонаційна концепція музики, яка представлена послідовником Б. Асаф'єва в Україні І. Ляшевським [7]. Також теоретичні розробки дослідників Д. Гачева [4; 5], М. Ремньової [11], Т. Попової [10], Т. Бояджиєвої [1; 3], Маслова Ю [8], які присвячені етапам формування й розвитку фонетики болгарської мови, природним факторам, що вплинули на їі специфіку. Окремо виділяємо праці болгарських науковців Абаджиєва А[1], Стефанова Тінтерова Ст. [13], що присвячені творчому шляху видатних болгарських оперних співаків. Детальний аналіз історії створення, особливостей першої слов'янської писемності знаходимо на сторінках праць Запольської Н. [6], Флоря Б. [15]. Проте вченими не приділено уваги аналізу тембральних переваг болгарської церковної та оперної музики у зв’язку з мовною фонетикою Болгарії.

Наукова новизна - вперше зроблено узагальнення про тембральні переваги болгарської церковної та оперної музики у зв’язку з мовною фонетикою Болгарії.

Мета статті - розглянути особливості фонетики болгарської мови та її впливу на формування болгарського вокалу.

Виклад основного матеріалу.На формування національної школи співу впливають як вокально-технічні особливості, так і характерні риси психологічного складу нації, витоки іiі музичної культури, історичний розвиток та мова. Психолог, філософ болгарського походження Г. Гачев все життя вивчав національні особливості культур цивілізацій. Він виявив феномен Космо - Психо Логосу як національної цілісності народу. «Подібно до того, як людина є потрійна єдність: тіло, душа, дух (розум) - так і кожна національна єдність є космо-психо-логосом, тобто єдність природи місцевості (космос), національного характеру (психея) і складу мислення (логос) [4, 354]. Науковець припускав, що звернувшись до внутрішньої форми слова або до його етимологічного аналізу, можна побачити в ньому у стислому вигляді ту думку, яка підштовхнула людей до творчого акту його створення, в результаті якого це слово стало надбанням цілого мовного колективу. Якщо взяти звучання мови (артикуляційні особливості, тембральне забарвлення, ритміку, гучність), то воно пов'язується в свідомості інших народів з тією культурою, частиною якої ця мова $є[4,8]$.

У зв'язку зі сказаним, звертаємо увагу на особливий мовний, фонетичний «грунт», який вплинув на формування прекрасних оперних голосів слов'янських народів, особливо Болгарії. У порівнянні з популярною сферою, де цю країну майже не представлено, масовий попит на болгарські голоси в провідних оперних театрах вражає, хоча середньостатистичний чоловік - тенор, і в цьому вся художня спокуса. Практика оперного співу показує, що після відомих оперних басів (I. Петров, С.Гулак-Артемовський, Ф. Шаляпін та ін.) болгарські баси, які представлені в оперному співі ХХ ст., - неперевершені.

Легендами опери минулого століття стали Б. Христов [13], М. Гяуров [12], С. Сленков, Г.Єнєв, Н. Гюселєв, Ю. Константінов, П. Манолов, Д. Пєтков, Д. Станчевта інші. Показово, що високі чоловічі голоси болгарських солістів не виокремлені, а серед жінок, особливо народжених в 
Південно-Східній частині Болгарії, переважають «великі» голоси з меццо-сопрановим запасом, серед яких - Г. Дімітрова, Р. Кабаіванська, А. Томова, Л. Веліч.

Вважаємо, що саме фонетика болгарської мови, яка досить близька фонетиці української, російської та італійської мов, $є$ показником національної особливості вокальної школи країни і стала основним фактором популярності та затребуваності болгарських оперних співаків.

Болгарську, українську та російську мови класифікують у мовознавстві як слов'янську групу споріднених мов індоєвропейської сім'ї. Уточнимо, що слов'янські мови за ступенем їхньої близькості прийнято ділити на 3 групи: східнослов'янську (російська, українська, білоруська), південнослов'янську (болгарська, македонська, сербохорватська, словенська) і західнослов'янську (чеська, словацька, польська) [2]. Відомо, що ці мови походять від одного з індоєвропейських діалектів - протослов'янського. На його основі сформувалась праслов'янська мова, яка i $\epsilon$ родоначальницею всіх сучасних слов'янських мов і аж до I тисячоліття н. е. розвивалась як єдиний діалект з тотожною структурою.

Протягом всієї праслов'янської епохи в мові відбувалися ряд змін, що мають у своїй основі загальні тенденції - тенденцію до висхідної звучності - встановлення в межах складу обов'язкового розподілу звуків відповідно до їхньої акустико-артикуляційної характеристики за принципом збільшення звучності кожного наступного звуку і тенденції до складового сингармонізму, згідно 3 яким, звуки в межах одного складу повинні були бути артикуляційно близькі один одному [11].

Як стверджує М. Ремньова, найважливішими процесами праслов'янського періоду були втрата закритих складів і пом'якшення приголосних перед йотом. У зв'язку з першим процесом, усі стародавні дифтонгові сполучення перейшли в монофтонги, виникли плавні склади, носові голосні, відбулося переміщення складорозділу, що викликало, в свою чергу, спрощення груп приголосних, явища міжскладової дисиміляції. У зв'язку з пом'якшенням приголосних перед йотом відбувся процес першої палаталізації задньопіднебінних. Саме палаталізація приголосних - наближення плоскої середньої частини язика до піднебіння при промовлені звуку $-\epsilon$ відмінною рисою слов'янських мов[11].

Майже всі приголосні звуки в слов'янських мовах можуть бути твердими (непалаталізованими) або м'якими (палаталізованими). Західноєвропейські мови не допускають пом'якшення приголосних, навіть перед голосними переднього ряду.

На подальший розвиток праслов'янської мови (VII - i по X ст.) вплинув дунайськобулгарський діалект, що поширився серед засновників Першого Болгарського царства на території нижнього Дунаю і привніс в мову глоси, адстратні і субстратні запозичення [9].

Процес переходу праслов'янської мови, ії діалектів в самостійні слов'янські мови був тривалим і складним. Найбільш активно він проходив у 2-й половині І-го тис. н. е., в період формування ранніх слов'янських феодальних держав на території Південно-Східної та Східної Європи. Ще в надрах праслов'янської мови почали виникати діалектні побудови. Найбільш диференційованою в діалектному відношенні була південнослов'янська група[2].

Головною відмінністю південнослов'янських мов від східно- та західнослов'янських $\epsilon$ збережена система відмінювання дієслів з безліччю минулих часів, в якій інфінітиву або немає взагалі (в болгарському), або його використання звужене. Для створення складових форм майбутнього часу в якості допоміжного дієслова використовується не «бути» або «мати» (як в українському), а «хотіти». Спрощено процедуру відмінювання (в болгарському до повного зникнення відмінків; у сербській та хорватській збіглися давальний, орудний і відмінки множини). У лексиці відчувається вагомий вплив східних мов(особливо, турецької) [8].

Класифікація слов'янських мов проводилася славістами за фонетичними ознаками. В основі класифікації лежала однакова або подібна переробка звуків i звукосполучень. Засвоївши методологічні концепції прамови і розщеплення іiі, славісти відповідно до кожної групи слов'янських мов реконструювали окрему прамову. Так, наприклад, західнослов'янська прамова передбачала однакову переробку груп «tort», «tolt» у всіх мовах цієї групи, а між тим, ми маємо в польській мові «-ro-», «-lо-», в чеській і словацькій «-ra-», «- la-» [11].

У XII - XIII ст. сталася втрата властивих праслов'янській мовіскорочених голосних ъ і ь. В одних випадках вони зникли, в інших перейшли в голосні повногоутворення. В результаті відбулися істотні зміни в фонетичній та морфологічнійбудові слов'янських мов.

Вперше літературну обробку слов'янські мови отримали в 60-х pp. IX ст. Творцями слов'янської писемності стали брати Кирило (КостянтинФілософ) і Мефодій. Вони перевели для потреб Великої Моравії з грецької мови на слов'янську літургійні тексти. У своїй основі нова літературна мова мала південно-македонський (солунський) діалект, але у Великій Моравії він 
увібрав у себе багато місцевих мовних особливостей [15]. У подальшому цей діалект отримав розвиток у Болгаріїі саме цією мовою була створена оригінальна і перекладна література в Моравії, Паннонії, Болгарії, на Русі, Сербіiі.

Існувало два слов'янських алфавіти - глаголиця і кирилиця. До IX ст. слов'янські тексти не збереглися. Найдавніші відносяться до Х ст. -Добруджанський напис (943 р.), напис царя Самуїла (993 р.) та ін. Основні пам'ятки датуються ХІ ст..

Слов'янські літературні мови епохи феодалізму, як правило, не мали суворих норм. Деякі важливі функції виконували інші мови (на Русі - старослов'янська).Уніфікація літературних мов, створення письмових і вимовних норм, розширення сфери вживання мови - все це характеризує тривалий період формування національних слов'янських мов[15].

Наразі слов'янські мови відрізняються великим ступенем близькості, яка виявляється в коренях, афіксах, структурі слова, граматичних категоріях, семантиці, системі регулярних звукових відповідностей, морфонологічних чергуваннях тощо. Вона пояснюється як спільним походженням, так і тривалими контактами на рівні літературних мов і діалектів.

Фонетика болгарської, української та російської мов відрізняється від західноєвропейської кількістю відкритих голосних. Фонетика (від грец. - «звук», «звуковий») - розділ мовознавства, що вивчає звуки мови і звукову будову мови (склади, звукосполучення, закономірності з'єднання звуків в мовний ланцюг). У болгарській мові розповсюджені зручні для співу «тверді» голосні. Адже вокалістам, що співають російською мовою, рекомендується «підміняти» в розспіві м'яке [є] звуком [e] i т. д. Болгарським вокалістам це майже не потрібно, як і українським співакам [11, 97]. В українській, порівняно 3 російською, «твердих» голосних більше - i це співвідноситься 3 фонетичними особливостями болгарської мови. Близькість української, болгарської, італійської та російської мов багато співаків-педагогів пояснюють фонетичною стороною мов, що вирізняються саме своєю сонорністю.

Акустично звуки мови поділяються на сонорні (звучні) і шумні. Сонорні вирізняються резонаторними тонами, шуми в них або зовсім не присутні (голосні), або беруть участь мінімально (наприклад, в [p] різного типу); в шумних (тільки приголосні) тембр визначається характером шуму. 3 точки зору лінгвістики сонорний тип мовлення затушовує значимість приголосних, в яких рясніють високі форманти. Апогей асонорності- німецька мова, і в цьому плані справедливим є спостереження В. Холопової щодо того, що всі європейці розмовляють і співають вище, ніж слов'янські народи, звідси більш світлий характер мови: «За загальним тоном звучання західна музика м'якша, ніжніша, вища за теситурою... пом'якшене і «тонше» забарвлення звуку до сих пір відрізняє західні хори та ансамблі... В м'якості і ніжності інтонації концентрується специфічний вид музикальності західноєвропейської культури»[14, 153].

На думку, Г. Гачева, довгота і стислість голосних в західноєвропейських мовах має вагоме значення, на відміну від російської аморфної довжини звуку. У музиці російська пісня відрізняється розспівом - протягуванням голосного звуку в залежності від настрою, від душі, а не так, як в німецькому Космо-Логосі, де протяжність або стислість від душі відділені, а суть форми об'єктивного існування сенсу, духу, розуму, як готові апріорні стандартні тривалості $[5,175]$.

Мова з опорою на голосні - це більш низькі форманти мови, хоча професійні співаки вчаться однаково добре співати у всіх регістрах, і все ж, Болгарія славиться своїми басами. У церковному співі Болгарії набула поширення «басова традиція» співу в храмах. Церковний композитор «першого покоління» музикантів Болгарії Добрі Христов виділяв бас як основний голос в партії. В сучасних літургіях також велике місце відведено басовій партії: вона виступає не тільки як гармонійна основа акордів, але і має розвинену мелодійну структуру.Такого роду нахил в серйозну сферу співочих ресурсів нації вважаємо не випадковим, притому, що опера Болгарії аж ніяк не становила виражену лінію в національній музичній сфері. Вважаємо, що в секуляризованій культурі XX ст. оперне мистецтво зайняло місце серйозного жанру, як до того церковна музика протистояла оперній світськості.

Яскравим підтвердженням «вокальної дружби» може стати біографія великого болгарського співака, переселенця з Нові Пазар в місто Болград Одеської області Івана Вульпе. У болгарській літературі його називають «основоположником болгарської оперної співочої школи, яка прославилася в усьому світі, і засновником Софійській опери» $[1,9]$. Музикознавець А. Абаджиєв уточнює: «Він поєднує найцінніше від італійського бельканто, російської традиції оперного перевтілення (найяскравіше представленої Федором Шаляпіним) і особливу голосову обдарованість болгар» $[1,3]$. 
Сучасні болгарські популярні співачки -Лілі Іванова і Валя Балканська вирізняються опорою на сильні грудні ноти. Голос В. Балканської в 1977 р.було відправлено до сузір'я Мала Ведмедиця в складі апаратів «Вояджер-1» $\mathrm{i}$ «Вояджер- 2». На борту апарата перебував золотий диск з музичними творами, серед яких родопська пісня «Вышел Делю гайдук» в її виконанні. I якщо Лілі Іванова ствердилася в якості поп-зірки соціалістичного табору, наповнивши естрадно-роковою динамікою слов'янський мелодизм, то представниця популярного мистецтва Валя Балканська в планетарному масштабі підтримує статус повільного споглядально-зосередженого співу фольклорної основи. Але при цьому співачка уникає показових для минулого століття енергійних ритмічних послідовностей, тим самим в іiі quasi-фольклорному співі впроваджена церковна «нескінченна» кантилена і церковна ж Православна серйозність.

Огляд історичних матеріалів з болгарської музики в єдності 3 проробленими аналізами мовної фонетики Болгарії дозволяють зробити висновок, що релігійна суворість болгарської традиції, сприятливі фонетичні дані зумовили вагомість болгарського вокалу в світовому вираженні цього мистецтва, а значимість басового співу для болгар в опері недвозначно змикається 3 церковною традицією. Звучання низьких голосів сполучається в староцерковній традиції з серйозністю, що надзвичайно важливо для усвідомлення Християнської ідеї. Не випадково в старовинних німецьких пасіонах партії Ісуса Христа завжди басові. Тому навіть спів естрадних зірок - опора на низькі ноти асоціюється 3 «серйозністю».

Входження пісень Валі Балканської в ряд хітів планетарного масштабу в кінці XX століття позначило новий ракурс прийняття болгарських національних стимулів культурою «поставангарду» в професіоналізмі і «построковою хвилею» в «третьорядовому» мистецтві.

\section{Jimepamypa}

1. Абаджиев А. И. Вульпе. Основоположник. София : БСПиМ, 2006. 30 с.

2. Бернштейн С. Б. Славянские языки // Лингвистический энциклопедический словарь / гл. ред. В. П. Ярцева. М. : Сов. энцикл., 1990. С. $460-471$

3. Бояджиев Т. Български говори в Западна (Беломорска) и Източна (Одринска) Тракия. София : Университетско издателство "Св. Климент Охридски", 1991. 276 с.

4. Гачев Г. Национальные образы мира. Космо-Психо-Логос. М.: Академический Проект, 2007. 512 с.

5. Гачев Г. Национальные образы мира: Общие вопросы Русский. Болгарский. Киргизский. Грузинский. Армянский. М. : Сов.писатель, 1988; М. : Прогресс, 1995. 233 с.

6. Запольская Н. Н. «Общий» славянский литературный язык: типология лингвистической рефлексии. М.: Индрик, 2003. 240 с.

7. Ляшевский С. История Христианства в Земле Русской с I по ХІ век. М.: ФАИРПРЕСС, 2002. 320 с.

8. Маслов Ю. С. Болгарский язык // Языки мира. Славянские языки. М. : Academia, 2005. С. 69-102.

9. Мудрак О. А. Заметки о языке и культуре дунайских булгар // OrientaliaetClassica VI, Аспекты компаративистики 1. M., 2005. URL: http://starling.rinet.ru/Texts/bulgar.pdf (дата звернення: жовтень 2018).

10. Попова Т.В. Некоторые вопросы восточноболгарского вокализма // Исследования по славянской диалектологии: Фонетический аспект изучения славянских диалектов. 2009. №14. С. 92-106.

11. Ремнева М. Фонетические процессы праславянского периода // Тезаурус «Гуманитарная Россия»/ Ремнѐ ва М.Л., Чернец Л.В., Маркина Л.А., Архангельская А.В., Семенов В.Б. и др. URL:http://www.philol.msu.ru/ tezaurus/library.php?view=d\&course=1\&raz=1\&pod=2\&par=5] (дата звернення: жовтень 2018).

12. Спомени за великия български оперен певец Николай Гяуров. URL : http://www.obektiv.info/?cat=9\&article=3438] (дата звернення: жовтень 2018).

13. Стефанов Тинтеров Ст. Името на бележитиябългарски артист Борис Христов. URL : http://borischristoff.net/pdf/olga.pdf] (дата звернення: жовтень 2018).

14. Холопова В. Неоевропоцентризм: музыкальная культура на рубежетысячелетий. Кн.1 / В. Холопова, Л. Канарис, Е. Маркова, С. Таранец. Одесса : Астропринт, 2006. 162 с.

15. Флоря Б. Н. Сказание о начале славянской письменности // Библиотека Якова Кротова. URL : http://www.krotov.info/history/09/3/flor_00.htm] (дата звернення: жовтень 2018).

\section{References}

1. Abadzhiev, A. (2006). I. Vulpe. The Founder. Sofia: BSPiM [in Bulgarian].

2. Bernstein, S.B. (1990). Slavic Languages.Linguistic Encyclopedic Dictionary. V.P. Yartseva(Ed.) M.: Sov. Encycl. [in Russian].

3. Boyadzhiev, T. (1991). Bulgarian language in Western (Belomorska) and Eastern (Odrinska) Thrace.Sofia: University Publishing House «St. Clement Ohridski»[in Bulgarian].

4. Gachev, G. (2007). National images of the world.Cosmo-Psycho-Logos. M.: Academic Project [in Russian]. 
5. Gachev, G. (1995). National images of the world: General questions Russian. Bulgarian.Kyrgyz.Georgian.Armenian. M.: Progress, 1995 [in Russian].

6. Zapolskaya, N. N. (2003). «General» Slavic literary language: typology of linguistic reflection. M.: Indrik[in Russian].

7. Lyashevskyy, S. (2002). History of Christianity in the Russian land with I the XI centuries. Moscow: FAIRPRESS [in Russian]. Russian].

8. Maslov, Yu. S. (2005). Bulgarian language. Languages of the World. Slavic languages. M.: Academia[in

9. Mudrak, O. A. (2005). Notes about the language and culture of the danubebulgars.Orientaliaet Classica, VI, Aspects of Comparative Literature. Retrieved from http://starling.rinet.ru/Texts/bulgar.pdf [in Russian].

10. Popova, T.V. (2009). Some questions of the eastern bulgarian vocalism. Investigations on Slavic Dialectology: The Phonetical Aspect of the Study of Slavic Dialects, 14, 92-106 [in Russian].

11. Remneva, M. Phonetic processes of the Slavic period. Thesaurus "Humanitarian Russia". Remnova M.L., Chernets L.V., Markina L.A., Arkhangelskaya A. V, Semenov V. B (Eds). Retrieved fromhttp: //www.philol.msu.ru/ tezaurus/library.php? View $=\mathrm{d} \&$ course $=1 \&$ raz $=1 \&$ pod $=2 \&$ par $=5$ [in Russian].

12. Memories of the great Bulgarian opera singer Nikolay Gyaurov. Retrieved from http://www.obektiv.info/?cat=9\&article=3438[in Bulgarian].

13. Stefanov, Tinterov Art. (n.d.). The name of the distinguished Bulgarian artist Boris Hristov.Retrieved fromhttp://borischristoff.net/pdf/olga.pdf [in Bulgarian].

14. Kholopova, (2006). V. Neoevropocentrism: Musical Culture at the turn of the V. Kholopova, L. Canaris, E. Markova, S. Taranets (Eds). Millennium, 1, Odessa: Astroprint[in Russian].

15. Florya, B. N. Legend of the beginning of Slavic writing. Library of YakovKrotov.Retrieved fromhttp://www.krotov.info/history/09/3/flor_00.htm [in Russian].

Стаття надійшла до редакиії 30.01.2019 p.

УДК 78. 03

Татарнікова Анжеліка Анатоліївна, кандидат педагогічних наук, викладач кафедри хорового диригування Одеської національної музичної академії iм. А. В. Нежданової

ORCID 0000-0002-6310-827

angelikatatarnikova75@gmail.com

\section{«GLORIA» Ф. ПУЛЕНКА В КОНТЕКСТІ ТРАДИЦЙ ХРИСТИЯНСЬКОГО СЛАВОСЛІВ'Я: ОБРАЗНО-СМИСЛОВІ І ЖАНРОВО-СТИЛЬОВІ АСПЕКТИ}

Мета роботи - виявлення поетико-інтонаційних особливостей «Gloria» Ф. Пуленка у руслі «неоканону» меси XX ст., а також особливостей відтворення поетики християнської музично-славословної традиції. Методологія роботи спирається на інтонаційну концепцію музики в ракурсі інтонаційностилістичного, етимологічного аналізу, спадкоємного від Б. Асаф'єва та його послідовників, а також на міждисциплінарний та історико-культурологічний підходи. Останні дозволяють виявити духовно-смислову та стильову специфіку «Gloria» Ф. Пуленка в контексті не тільки індивідуального авторського стилю, але й еволюційних шляхів духовного хорового музичного мистецтва Свропи. Наукова новизна статті визначена іiі аналітичним ракурсом, що враховує як жанрові «моделі» католицької меси, починаючи з епохи Середньовіччя, так і особливості відтворення семантико-риторичної специфіки Gloria-славослів'я в однойменному творі Ф.Пуленка. Висновки. Твір Ф. Пуленка за своїми жанрово-інтонаційними показниками апелює до європейської духовно-музичної традиції трактування Gloria як християнського славослів'я, що остаточно склалася у композиторській практиці Нового часу. Сказане $є$ очевидним і в зверненні композитора до кантатного типу побудови Gloria як мікроциклу, і в паралелях з поетикою однойменної кантати А. Вівальді, і в апелюванні до музично-риторичного глоріозного комплексу, і в використанні барочних протиставлень solo та tutti. Paзом 3 тим, «Gloria» Ф. Пуленка виявляє індивідуальність авторського підходу до відтворення поетики християнського славослів'я, що є очевидним в домінантній ролі монодійності, хоральності, бурдонних побудов, уникненні акордовості функціонально-класичного типу та поліфонічних форм (фуга), що в сукупності виявляє типові риси «неоканону» меси XX ст. Ф.Пуленка.

Ключові слова: меса, Gloria, християнське славослів’я, хорова творчість Ф. Пуленка, «Gloria»

(C) Татарнікова А. А., 2019 